\title{
THE MAP OF LANDSCAPE USE OF CENTRAL EUROPE
}

The map of use of landscape presents relations between land use and landscape pattern. The land use pattern is analysed within the borders of natural units existing in nature (geocomplexes or geosystems). The way of doing it differs fundamentally from the commonly applied analysis of land use within the administrative limits.

These maps were worked out with the variable accuracy in various scales. The first general map of this kind was elaborated in the scale 1:750,000 for the area of the former GDR by a team headed by H. Richter (Richter, 1981). In the background of the groups of the types of "natural space" (Naturraumtypen) differentiation of land use was marked. The use of land was considered in division on five main complexes: settlement areas, areas of opencast exploitation of natural resources, agricultural areas, forest complexes and areas of mixed agricultural-forest use.

The same approach was applied at the elaboration of the map of landscape use of Poland in the scale 1:500,000 (Richling, Lewandowski, 1988). Because of different property relations farmland in Poland is much more dispersed and mosaic-like. In the consequence it was necessary to classify in more detail of land use. Following types were introduced: settlement and urban areas, mining-industrial areas, forests, farmland, grassland, orchards and vegetable growing areas and 3 types of mixed land use - agricultural-forest, agricultural-meadow and meadow-forest one. The above mentioned categories of land use were combined with the classification of natural landscapes. The map presents classes, sorts and kinds of landscape.

Apart from review presentations there are examples of maps of landscape use in the more precise scales. W. Lewandowski is the author of the map of landscape use of the fragment of Plock voivodeship in the scale 1:100,000 and the area of Whocławek voivodeship* in the scale 1:50,000 (Lewandowski, Ostaszewska, 1990). The elaboration of these maps demanded a somewhat different approach, particularly large share of field studies at the mapping of natural units, as well as at investigation of the way of area organization.

\footnotetext{
* voivodeship — the highest rank unit of administrative division of Poland
} 


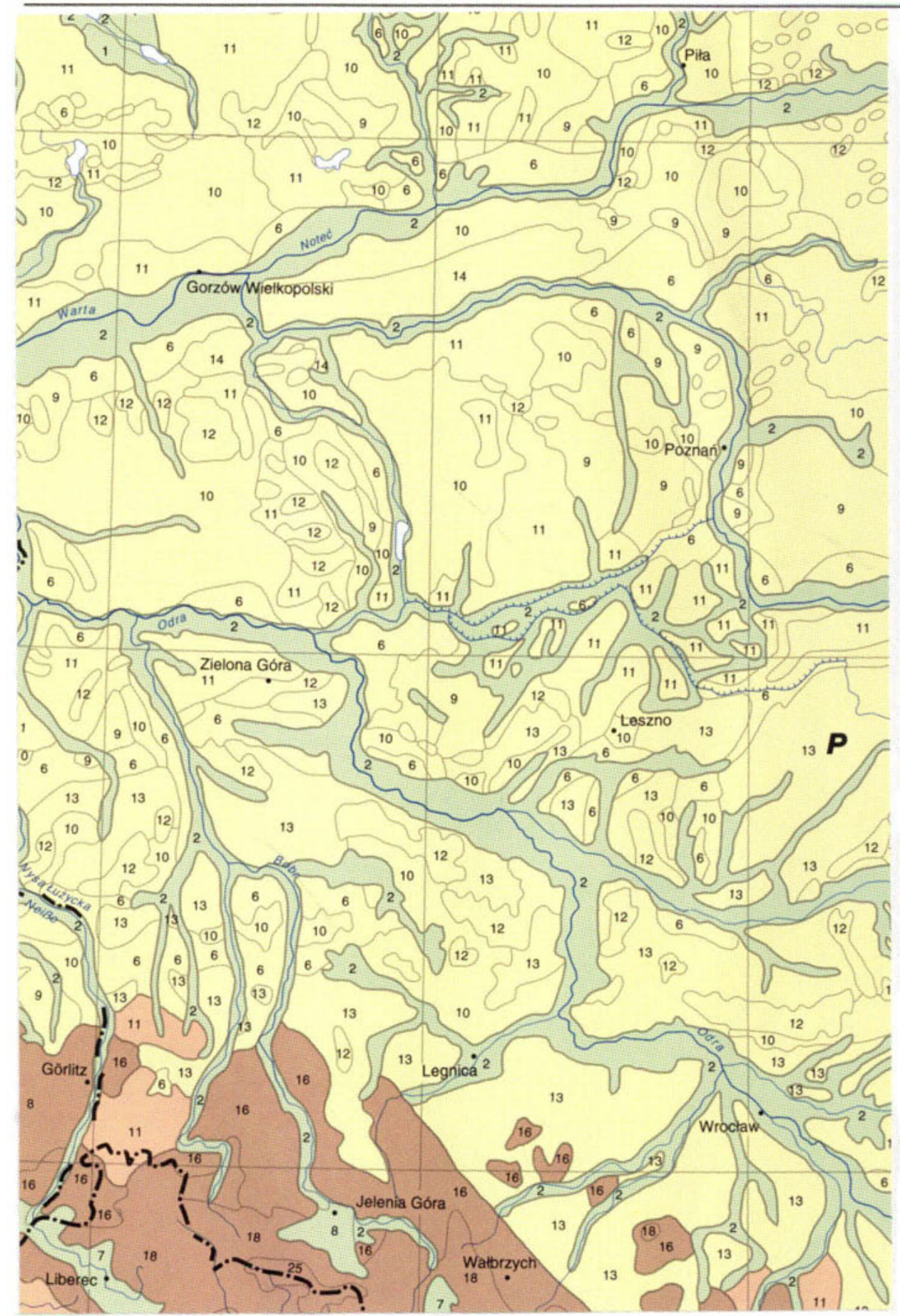

Fig. 1. Fragment of the map of landscape units 


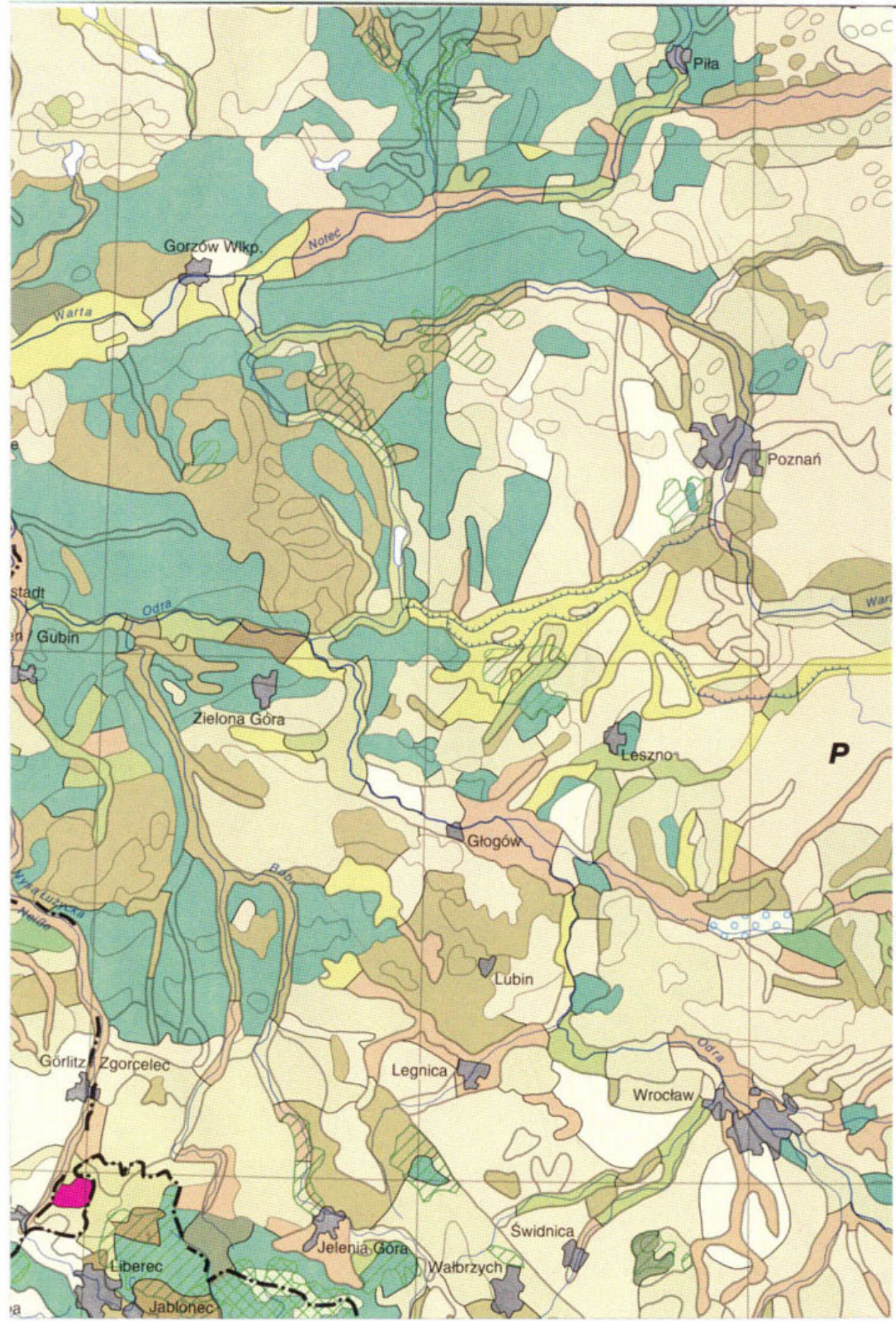

Fig. 2. Fragment of the map of land use 
The maps of landscape use may also serve for detailed analysis and are elaborated in the scales 1:25,00 and 1:10,000. The basic units then are geocomplexes distinguished with an assumption of a primary role of relief and lithology as well as water depth in the ground. The structure of the units is studied on the lines of landscape cross-section which permits to examine also a vertical differentiation of the geocomplexes. The next stage is an evaluation of natural potential of particular geocomplexes. The executors of the elaboration make use of special table-matrix which shows correct kinds of land use according to the bed rock, soil types and subtypes, slope value and wetness of the habitat. Possibilities of the cultivation of the plants depend to a large extent on the slopes. Along with the growing slope value and a threat of erosion field crops give way to orchards and vegetable gardens. The most steep slopes should be afforested. In such a case a type of forest community is proposed. A comparison of the proposed way of land use with the existing one constitutes a basis for elaboration of separate map of evaluation of landscape use. In the map all geocomplexes are divided into exploited in an optimal (correct) way and used incorrectly from the viewpoint of natural predispositions.

The project of elaborating a map of landscape use of Europe or a part of it has been existing for many years and it was discussed in the framework of scientific cooperation between the countries of Eastern Europe. It was recently presented by the undersigned in response to an appeal of the Institute of Geography of the Czech Academy of Sciences. The Austrian Institute of East and South-East European Studies has expressed its interest in this elaboration. At the end of 1992 during a meeting with dr P. Jordan representing the Austrian Institute it was agreed that in the Atlas of Eastern and Southeastern Europe a map in the scale 1:1,500,000 presenting the coincidence of natural landscape units and lands use will be elaborated. The study will concern the central part of Europe comprising Slovakia, Czechia, Hungary, large parts of Poland, Austria, Slovenia, minor parts of Germany, Croatia, Serbia, Romania and the Ukraine. It was also decided that in order to improve the readability of the map it will be elaborated in the form of two sheets, one representing natural landscape units and one representing land use. To make the correspondence between two maps clear enough the boundaries of the natural units will be also presented on the map of land use.

The map was elaborated under the direction of A. Richling and W. Lewandowski and A. Dabrowski was responsible for the cartography. Besides the above mentioned persons, representing the Faculty of Geography and Regional Studies of the Warsaw University, the following persons took part in the elaboration of the map: M. Seger, U. Horn and P. Jordan from Austria, Z. Stiperski - Croatia, J. Kolejka, M. Koželuh and V. Nováček - Czechia, L. Bassa and P. Csorba - Hungary, G. Schönfelder - Germany, J. Otahel and J. Ferenec - Slovakia, K. Natek - Slovenia, G. Miller and S. Stoyko - Ukraine. 
The methodics of the map's elaboration and the progress of the works were discussed on three meetings: on 26 February 1993 in Warsaw, organised by the Faculty of Geography of Warsaw University, on 3 September 1993 in Bratislava, organised by the Institute of Geography of the Slovak Academy of Sciences and on 18 March 1994 in Brno, organised by the Institute of Geonics of the Czech Academy of Sciences. The Austrian Institute of East and South-East European Studies cooperated in organizing of the last two meetings.

The basis for delimination the natural dimensional units was constituted by the map of Natural Landscape Types from the Atlas of the Danubian Countries published in the scale $1: 2,000,000$ by the Austrian Institute of East and South-East European Studies. Contents of map were enriched and modified. The classification of natural landscapes was enriched with categories of glacial landscapes dominant in the north, on the territories of Germany and Poland. Also a new version of the classification of Poland's landscapes in the scale 1:1,500,000 elaborated for the needs of the National Atlas was used. Every type of landscape is characterised by landforms, soils and natural vegetation.

The land use varies strongly, 16 categories were selected, the major part being mixed types. In the final version, according to $P$. Jordan's proposal this classification was presented in a simplified form which emphasizes the dominant function of the terrain. The following categories were introduced:

Settlement and built-on land

Mining, industrial use

Industrial use (large industrial plants, waste-heaps, dumping grounds)

Mining (opencast mines)

Agriculture

Crop production

Annual crop production (75-80\% of the area)

with predominance of small farms

with predominance of large estates

Annual crop production with a substantial share of perennial crop production and horticulture ( $=50 \%$ of the area)

Annual cropping with fruit cultivation

Annual cropping with vine growing

Annual cropping with hop growing

Perennial crop production, special cultivations, horticulture

( $>70 \%$ of the area)

Fruit cultivation, horticulture

Vine growing

Hop growing

Livestock production (grasslands covering $>70 \%$ of the area)

Intensive livestock production (mostly; on artificial and semi-natural meadows and pastures) 
Extensive livestock production (mostly on natural meadows and pastures, marshlands, alpine meadows and pastures)

Mixed crop and livestock production with predominance of arable lands (ratio crop production: livestock production $=60: 40 \%$ ) with predominance of grasslands (ratio grasslands: arable lands $=60: 40 \%$ ).

Agroforestry

Predominantly annual cropping, dispersed forestry on $<30 \%$ of the area Predominantly annual cropping, substantial share of dispersed forestry, but on $<50 \%$ of the area

Predominantly annual cropping (on $=60 \%$ of the area) with forestry and livestock production

Sylvopastoral type with predominance of forests (ratio forests:

grasslands $=70: 30 \%$ )

Sylvopastoral type with predominance of permanent natural or semi-natural grasslands and with dispersed forests

(ratio forestry: extensive livestock production $=60: 40 \%$ )

Mixed forestry, crop and livestock production (similar shares)

Forestry (compact forest complexes covering at least $80 \%$ of the area)

Broadleaved forests

Coniferous forests

Mixed forests

Unused land

Besides the above-mentioned categories, the following supplementary were presented on the map: national parks, landscape parks, surface waters including bigger artificial lakes, substantial share of fish ponds.

When elaborating the map areas larger than 20 square kilometers in reality which corresponds to 9 square milimeters on a map, were included.

The text related to elaboration contains the following data: methods of elaboration, sources, regional differentiation of the land use pattern and prognosis of the future situation. More detailed examples of graphic studies of relations between land use and natural predispositions of the terrain were included in the text. These examples are intended to serve for a presentation of various methodical solutions and different regional situations.

Summing up, it is necessary to emphasize the importance of the presented approach for practical aims. The maps of landscape use should be useful first of all in planning. They permit to evaluate the way of utilizing natural resources, to introduce new forms of land use and to optimalize the way of geographical space organisation. They should be a basis for environmental management and protection. The role of such maps in the ecological education of the society should be also stressed. 


\section{REFERENCES}

Lewand owski W., Ostaszewska K., 1990, Maps of the ecological structure of the area and landscape use in the scale 1:50000 (on the example of the Włocławek Voivodeship). in: Ecological Management of Landscape, Warszawa.

Ökologie der Landnutzung in Mitteleuropa, Atlas Ost- und Südosteuropa, 1,4-M $\mathrm{M}_{2} \mathrm{~A}$ Landschaftseinheiten, 1,4- $\mathrm{M}_{2} \mathrm{~B}$ Landnutzung und Begleittext. Herausgeber Österreichisches Ost- und Südeuropa Institut, Wien 1996.

Richling A., Lewand ow ski W., 1988, The Map of Landscape Use, Miscellanea Geographica.

Richter H., 1981, Die inhaltliche Konzeption der Karte "Flachennutzung und naturräumliche Ausstatung" 1:750000 im "Atlas DDR". Pet Geogr. Mitt. 3. 
